УДК : 338. 48

JEL: M31, L83

(C) Кифяк О.В., 2021

o.kyfyak@chnu.edu.ua

Чернівецький національний університет імені Юрія Федьковича, Чернівиі

\title{
ВИКОРИСТАННЯ МАРКЕТИНГОВИХ ІНСТРУМЕНТІВ В УМОВАХ ТРАНСФОРМАЦІЇ РЕГІОНАЛЬНОГО РИНКУ ТУРИЗМУ
}

\begin{abstract}
Визначено основні маркетингові інструменти, які можуть бути використані в сучасних умовах трансформації регіонального ринку туризму, зокрема, діджиталізація системи збуту та просування туристичного продукту, інтенсифікація реклами, орієнтація на маркетингове ціноутворення, використання системи зв'язків з громадськістю та активізація маркетингових досліджень. Окрема увага у статті зосереджена на результатах SWOT-аналізу туристичного потенціалу західноукраӥнських прикордонних територій.
\end{abstract}

Ключові слова: маркетингові інструменти, туризм, дестинація, діджстталізація, SWОТ-аналіз.

Глобальні трансформаційні процеси, що відбуваються у сфері туризму не оминули і регіональні туристичні ринки. Характерною рисою зміни структурних сегментів регіонального ринку туризму став нерівномірний розподіл туристичних потоків за типом організації відпочинку. Якщо в період 80-90 років минулого століття внутрішній та міжнародний туризм практично на $80 \%$ формувався за рахунок групового сегменту, то на початку XXI ст. вже $60-70 \%$ від загального обсягу туристичних потоків почав складати індивідуальний туризм (до цієї кількості також відносяться туристи, що подорожують в тому числі і в зарубіжні країни).

Постановка проблеми. Поширення коронавірусу COVID-19, закриття кордонів, введення карантинних обмежень, зміна економічної ситуації та зростання політичної напруги - все це привело до змін в поведінці споживачів туристичних послуг, в результаті яких туристичним підприємствам і туристичним дестинаціям доводиться шукати нові підходи до сегментації ринку, змінювати способи просування туристичного продукту, активізувати онлайн-потенціал, формувати унікальні туристичні пропозиції. Важливу роль при цьому відіграють маркетингові інструменти, які дозволяють здійснити трансформації ринку туризму максимально ефективно.

Аналіз останніх досліджень. Проблеми використання маркетингових інструментів для здійснення ефективних зрушень на туристичному ринку $\epsilon$ предметом наукового інтересу ряду закордонних та вітчизняних фахівців. Так, маркетингові рішення та інструменти висвітлюються в роботах іноземних класиків, зокрема, Р. Бертона, Ф. Котлера, Дж. Холловея, серед українських авторів, які досліджували проблеми туризму, відомими $\epsilon$ прізвища I. Буднікевич, О. Євтушенка, В. Кифяка, М. Мальської, основні проблеми, викликані пандемією коронавірусу у світі та Україні досліджуються у працях таких авторів, як Я. Жаліло, С. Ковалівська, А. Филипенко, В. Химинець, А. Головка [1], сучасні тренди розвитку туризму визначаються у спільних дослідженнях В. Липчука та Н. Липчук [2], регіональні аспекти трансформації туристичної галузі вивчають М. Білецький, Л. Котик [3]. Усе це підтверджує важливість цієї проблематики як 3 погляду практики, так і для удосконалення теоретико-методологічних засад розвитку туризму.

Мета та завдання статті. Пошук можливостей використання маркетингових інструментів в умовах трансформації регіонального ринку туризму шляхом вивчення кращих практик зарубіжного та українського досвіду, проведення маркетингових досліджень та аналізу потенціалу територій західноукраїнських прикордонних регіонів.

Виклад основного матеріалу дослідження. Сьогодні пандемія загострила конкуренцію на туристичних ринках, а тому регіонам, які хочуть приймати туристів, доводиться підлаштовуватися під їхні оновлені запити, слухати i чути побажання існуючих та потенційних клієнтів. Про трансформацію туристичних регіональних ринків свідчить досвід суб'єктів туристичної діяльності західноукраїнських прикордонних областей, які пропонують нові маршрути, знижують ціни на свої послуги і вже тепер ефективно просувають дестинації, туристичні продукти, маршрути, тури i об'єкти туристичної інфраструктури, активно застосовуючи при цьому цифрові технології. 
Одним з регіонів, що активно розвивається в цьому напрямку, є Львівська область, де діджитал-сервіси стали перспективними інструментами просування характерних та супутніх туристичних послуг. Пандемія продемонструвала, що туристам зручніше самостійно бронювати собі туристичні поїздки онлайн, починаючи від проїзду i закінчуючи послугами екскурсоводів. Це, власне, є трендом останніх років, який в умовах пандемії тільки посилився. Інновацією туристичного ринку Львівської області $є$ розвиток віртуального туризму (вид туризму XXI ст., який передбачає віртуальне відвідування та споглядання особою природно-, історико-культурних об'єктів засобами сучасних інформаційно-комп'ютерних технологій i комунікацій у будь-якій точці простору у режимі он-лайн) [3].

Розвиток віртуального туризму на перших етапах передбачає оцифрування фондів музеїв, підготовку 3D-зображень історичних частин поселень, внутрішніх інтер'єрів окремих історико-культурних споруд (замків, палаців, фортець, сакральних споруд тощо), а це вимагає колаборації сфери туризму 3 інформаційнокомунікаційною сферою. Як зазначають М. Білецький та Л. Котик, «на території Львівської області розвиток віртуального туризму у рамках «Комплексної програми розвитку культури Львівщини на 2018-2020 роки» підтримав Львівський IT-кластер, за допомогою інформаційно-технічних i кадрових ресурсів компаній якого 2018 року започаткований інтерактивний музейний проект «Відвідай». Результатом його втілення $\epsilon$ нанесення на віртуальну музейну карту світу 25 музеїв області» [4].

Ще одним прикладом активного використання цифрових продуктів для туристів у Львові $є$ їх залучення до культурних подій, які, попри карантин, відбуваються у безпечному режимі онлайн. Так, наприклад, у квітні 2021 року «доступні онлайн вистави «Іфігенія в Авліді», «Королева краси», «Пропала грамота», концерт оркестру INSO-Lviv, записи Соломії Крушельницької 1951 року» [5].

Для розвитку внутрішнього та в'їзного туризму та використання кращого туристичного досвіду, важливим завданням є створення умов для формування туристичної екосистеми, що об'єднає всіх учасників ринку на онлайнплатформі, інтегрованої з зовнішніми джерелами даних і соціальними платформами.

Таким чином, впровадження цифрових інструментів - це відповідь не тільки на мінливу структуру i канали споживання, але i незаперечний стимул для розвитку всіх суміжних галузей та трансформації туристичного ринку західноукраїнських прикордонних областей.

Важливим маркетинговим інструментом в період трансформації регіонального туристичного ринку залишається реклама туристичних продуктів, в тому числі i некомерційна реклама за рахунок бюджетних коштів держави та органів місцевого самоврядування. Дані Всесвітньої туристичної організації (ЮНВТО) та дослідження зарубіжних вчених свідчать, що для додаткового залучення одного іноземного туриста, який забезпечує вливання в економіку країни в середньому 1000 євро, держава витрачає від 3 до 10 євро на некомерційну рекламу туристичного продукту. У відповідності 3 цим середній обсяг бюджетних коштів, що виділяються в європейських країнах на просування туристичного продукту складає 31,7 млн. євро [6].

Дослідження туристичного західноукраїнських прикордонних областей свідчить, що на відміну від багатьох інших сфер діяльності, реклама в туризмі $є$ затребуваною туристом. Споживач сам звертається до реклами дестинацій і туристичних фірм тому, що не може безпосередньо оцінити продукт i змушений шукати інформацію і створювати образ. Аналіз рекламної продукції сприяв встановленню основних видів реклами, що використовується туристичними фірмами та туристичними дестинаціями. Це, насамперед, інтернет-реклама, соціальні мережі, а також друкована реклама в газетах i журналах, телевізійні ролики, путівники, зовнішня реклама, брошури, туристичні ярмарки, виставки, салони. Реклама представляє пропозиції фірм i дестинацій, їх основні переваги та є основним маркетинговим інструментом просування туристичних продуктів на регіональних, національному та міжнародному туристичних ринках. Ефективна реклама, формуючи бренд дестинації, дозволяє туристові після повернення демонструвати факт подорожі серед свого оточення.

Відносно новим інструментом в умовах трансформації регіонального ринку туризму $\epsilon$ інтернет-маркетинг _ - впровадження інформаційних технологій 3 метою підвищення ефективності діяльності туристичних підприємств.

Перевагами інтернет-маркетингу $\epsilon$ необмежений обсяг інформації, поєднання текстової, відео та аудіо інформації та швидке іiі оновлення, зберігання файлів i баз даних, необмежене число користувачів та двосторонній характер комунікації, відсутність географічної 
прив'язки, необмежений доступ за часом, відсутність витрат на розширення аудиторії, можливість прямих інтернет-продаж.

Досвід регіонів Польщі, Словаччини, Угорщини та Румунії, що мають транскордонну співпрацю 3 західноукраїнськими прикордонними областями, підтверджує ефективність цінового стимулювання збуту туристичних продуктів, особливо на внутрішні маршрути та індивідуальні автомобільні тури, що значно знижує ризики вірусного захворювання. Зниження ціни в низький сезон, особлива ціна при придбанні турів заздалегідь (раннє бронювання), спеціальні ціни на санаторно-курортне лікування й оздоровлення, впровадження комплексних карт знижок - все це може стимулювати збут туристичних продуктів i в прикордонних регіонах України.

Окрім цього, до сучасних інструментів збуту можна віднести різноманітні конкурси на знання міста чи території, розіграші безкоштовних путівок, подарунки при купівлі туру, сертифікати на безкоштовне відвідування театрів, музеїв, виставок, спортивних та інших закладів. закладів культури, спорту.

He менш важливими в просуванні туристичних дестинацій та окремих туристичних продуктів є зв'язки 3 громадськістю. Нині головною метою PR $є$ створення позитивного образу дестинації (туристичного продукту) у свідомості потенційного споживача, встановлення і підтримка взаємовигідних відношень між дестинацією i суспільством, насамперед тих регіонів, до яких формуються туристичні потоки та від яких залежить ефективність туристичного бізнесу.

Водночас, не всі складові управління маркетингом в туризмі враховуються суб'єктами туристичної діяльності та регіональними органами влади. Так, зокрема, якщо виробництво туристичного продукту та збут вважалися основними об'єктами маркетингового вивчення, то, за оцінками дослідження, дотичні види економічної діяльності, які продукують як характерні, так і супутні туристичні послуги, та безпосередньо споживачі (туристи) також виступають учасниками маркетингових відносин i дій. Отже, слід використовувати таку маркетингову модель, яка враховує всі групи маркетингового вивчення туристичного ринку (виробництво туристичного продукту, його збут, дотичні види економічної діяльності та споживачі), дозволяє проводити всебічне вивчення ринку i розробляти стратегії маркетингових дій $з$ урахуванням особливостей становища суб'єктів управління в моделі.
Опитування менеджерів туристичних операторів міста Чернівців, в період пандемії (серпень-жовтень 2020 р.), свідчать, що маркетинговою діяльністю займаються тільки невелика кількість туристичних підприємств, та й ті під тиском обставин. Так, зокрема, різке зниження обсягів реалізації активізувало вивчення споживчих переваг на туристичному ринку Буковини, розширення туристичних пропозицій, пошук неосвоєних ринкових ніш та переорієнтацію на внутрішній та індивідуальний туризм. Враховуючи те, що Чернівецька область в цілому і м. Чернівці, зокрема, мають значний туристичний потенціал та зорієнтовані на прийом іноземних туристів та відвідувачів 3 інших регіонів України, виникає необхідність зміни підходів до визначення структури туристичного потенціалу та оцінки його основних складових. Проведені опитування підтверджують, що туристичний потенціал - це не тільки набір послуг, необхідних для створення туристичного продукту, але й умови попиту, стан конкуренції на внутрішньому туристичному ринку та рівень розвитку підтримуючих галузей. Такий підхід дозволяє маркетологам здійснювати успішний пошук конкурентних переваг, розробляти заходи щодо підвищення якості послуг до рівня, що відповідає вимогам споживачів і формувати продуктові стратегії.

Одним 3 найефективніших інструментів маркетингу та стратегічного планування залишається SWOT-аналіз, вперше використаний К. Ендрюсом у 1963 році в контексті конференції, присвяченої проблемам ділової політики. Так, при підготовці до створення туристичних дестинацій SWOT-аналіз допоможе чітко зрозуміти позиції майбутньої дестинації на ринку, можливі перспективи та наявні проблеми.

Найважливіше завдання SWOT-аналізу допомогти місцевим органам самоврядування побачити та оцінити всі чинники, що впливають на прийняття рішень щодо створення туристичної дестинації, а також визначити можливості їі розвитку.

Згідно методики, SWOT-аналіз в першу чергу передбачає аналіз внутрішніх чинників. До цієї групи належать сильні (S) та слабкі сторони території (W), що визначаються ресурсами, які $\epsilon$ у розпорядженні регіону, а також процесами, на які органи місцевого самоврядування мають безпосередній вплив.

Позиції території оцінюють за такими критеріями: 
туристичні ресурси: природні рекреаційні та антропогенні ресурси, визначні пам'ятки історії, культури, архітектури,

- розвиток загальної інфраструктури: дороги, вокзали, аеропорти, комунікації, лікарні, торговельні центри, кінотеатри тощо.

розвиток туристичної та рекреаційної інфраструктури: готелі, санаторії, будинки відпочинку, гірськолижні комплекси, заклади харчування, анімаційні заклади та ін.

- людські ресурси: підготовлені фахівці, співробітники, цільова аудиторія, волонтери;

- внутрішні процеси: тренінги, мотиваційні програми для персоналу та програми лояльності для клієнтів, ієрархічна структура тощо.

- джерела фінансування, можливості отримання доходу, інвестиції.

Тільки після досконального розгляду і оцінки внутрішніх чинників, переходять до аналізу зовнішніх чинників, до яких відносяться можливості (O) i загрози (T), що прямо чи опосередковано впливають на формування туристичних дестинацій. Місцеві органи влади та туристичний бізнес регіону не здатні контролювати ці процеси, однак повинні їх знати та враховувати під час розробки стратегії.

До зовнішніх чинників належать:

- ринкові тенденції: поява нових туристичних продуктів чи технологій, зміни споживчих вподобань цільової аудиторії;

- відносини з клієнтами та постачальниками;

- економічні тенденції: глобалізація чи захист національних виробників туристичних продуктів, конкуренція, зміна туристичного попиту;

- зовнішне фінансування;

- демографічні показники: чисельність та вік населення, купівельна спроможність, цінності;

- політичні, екологічні, економічні обмеження та регуляції (ліцензії, квоти та ін.).

Для визначення стратегічних пріоритетів формування та розвитку туристичних дестинацій та розкриття сильних сторін західноукраїнських прикордонних регіонів, а також щоб зрозуміти слабкі сторони (недоліки) необхідно відповісти на основні питання:

- Що можна зробити краще, ніж конкуренти?

- Які переваги мають західноукраїнські прикордонні регіони з погляду туристів?

- $\quad$ Чи $є$ унікальний туристичний продукт?

- Що можна покращити в туристичному

продукті та в процесі надання послуг?

- Які негативні відгуки залишають туристи?

- Шо зменшує дохід?
Чи є речі, які конкуренти роблять краще?

При аналізі зовнішніх чинників необхідні відповіді на запитання:

- $\quad$ Чи існують додаткові напрямки розвитку туризму?

- Які цікаві тенденції з'явилися у ніші створення туристичних дестинацій?

- Які економічні, політичні, демократичні чи соціальні зміни принесуть користь створеним дестинаціям?

- Чи використовують конкуренти більш сучасні технології та пропонують кращий сервіс?

- Які зовнішні перепони $€$ на шляху формування дестинацій?

- Як сильно слабкі сторони погіршують позиції регіонів на ринку?

- Наскільки успіх залежить від зовнішніх чинників (зміна стандартів якості, припинення фінансування від донорів чи держави, обмеження продажів та ін.).

При отриманні відповідей на ці та інші питання, а також визначивши усі чинники, буде значно простіше прийняти рішення щодо того, чи посилити слабкі сторони завдяки наявним ресурсам чи відмовитися від ризикованого напрямку розвитку, зменшивши потенційні зовнішні загрози.

Загалом стратегії мають бути сфокусовані на акумуляції сил та використанні можливостей, що дозволить уникнути чи подолати загрози.

У контексті визначення стратегічних пріоритетів та розробки стратегії формування та розвитку туристичних дестинацій проведено SWOT-аналіз потенціалу західноукраїнських прикордонних регіонів. Для уникнення громіздких таблиць, наведемо лише спрощений варіант, який демонструє основні чинники. Для кожного з них була визначена позиція регіону по відношенню до регіонів-конкурентів (методом експертних оцінок у п'ятибальному діапазоні: 5 - найсильніша, 4 - сильна, 3 - середня, 2 слабка, 1 - найслабкіша) та ранг (вагомість даного чинника), визначений методом експертних оцінок у трибальному діапазоні: 3 найважливіший, 2 - важливий, 1 - неважливий.

$$
\text { До переваг західноукраїнських }
$$
прикордонних регіонів можна віднести:

1. Наявність унікальних природнорекреаційних (лікувально-оздоровчих) ресурсів.

2. Наявність культурно-історичних та архітектурних пам'яток світового рівня.

3. Історична спадщина міст i сіл, збереженість самобутньої культури та народних ремесел.

4. Вдале географічне та геополітичне розташування. 
5. Національно-етнографічна особливість західноукраїнських областей.

6. Розвинена гідрографічна мережа - (річки Дністер, Прут, Тиса, Черемош, Сирет, Західний Буг, Прип’ять, озера Світязь, Шацькі та ін).

7. Карпатські гори, що займають $4 \%$ території України (вражаючий пейзаж, рельєф і клімат).

8. Розвинута готельна інфраструктура.

9. Розширена мережа санаторіїв, будинків відпочинку, інших оздоровчих закладів.

10. Формування комплексного туристичного продукту на основі розвитку різних видів туризму.

11. Існування досвіду прийому туристів.

12. Наявність кордонів (митниць) 3 Польщею, Словаччиною, Угорщиною, Румунією, Молдовою.

13. Порівняно висока пропускна здатність рекреаційного господарства та рівномірність його використання (вплив сезонності маловідчутний).

14. Стабільна соціально-політична ситуація, відсутність міжнаціональних та міжрелігійних конфліктів.

15. Позиціонування областей в якості привабливого і безпечного місця відпочинку

16. Визнання на туристичних ринках, в т. ч. міжнародних, відносно позитивний імідж областей.

17. Значна кількість об’єктів релігійного паломництва.

18. Гостинне населення, вишукана різноманітна національна кухня.

19. Розвинута транспортна мережа та близькість до кордонів (міжнародне залізничне, автомобільне та авіа сполучення(4 міжнародних аеропорти).

20. Функціонування єврорегіонів «Буг», «Карпатський», «Верхній Прут» та встановлені транскордонні туристичні контакти.

21. Розвинутий науково-освітній комплекс. Забезпечення багаторівневої системи підготовки кваліфікованих кадрів для туризму.

22. Чисте навколишнє середовище, порівняно невисоке забруднення внаслідок аварії на ЧАЕС.

23. Зростання якості та асортименту рекреаційно-туристичних послуг, тенденція до нарощування обсягу наданих послуг.

24. Зростання обсягів приватних інвестицій у розбудову туристичної інфраструктури.

25. Визнання туристичної сфери пріоритетним напрямком розвитку областей.

До недоліків, які перешкоджають розвитку туризму, віднесемо:
1. Недостатність інформації про туристично-рекреаційний потенціал областей, особливо за межами України, недостатність туристичних карт, довідників, рекламної продукції.

2. Нерозвинутість інституціональної основи розвитку туризму.

3. Високий рівень зносу наявної інженернодорожної інфраструктури та недосконалі умови прибуття та пересування туристів.

4. Відсутність програми просування національно-етнографічної спадщини областей.

5. Зниження конкурентоспроможності турпродуктів областей, пов'язане 3 обмеженням можливостей надання туристичних послуг на рівні, відповідному світовим стандартам.

6. Відсутність гарантій якості послуг, невідповідність ціни і якості їх надання.

7. Концентрація туристичних ресурсів в окремих територіях і районах та нерівномірність розміщення закладів інфраструктури в територіально-адміністративному розрізі.

8. Відсутність розроблених та впроваджених маршрутів на релігійну тематику.

9. Наявність подібних туристичних пропозицій та можливостей на територіях інших учасників єврорегіонів «Буг», «Карпатський», «Верхній Прут».

10. Зниження стабільності функціонування виробничих систем, загроза техногенних та екологічних катастроф.

11. Слабка маркетингова політика по просуванню областей як привабливого туристичного напрямку, відсутність відповідного іміджу, бренду територій. Стримування можливостей реалізації туристичного потенціалу областей.

12. Відсутність наукового обгрунтування стимулювання процесів формування туристичних дестинацій та їх розвитку, недостатність коштів для проведення маркетингових досліджень та реклами туристичних можливостей областей.

13. Недостатнє забезпечення автодоріг туристичною, сервісною та інформаційною інфраструктурою (відсутність мотелів, СТО, кафе, кемпінгів, рекламних щитів та єдиної системи маркування автошляхів щодо закладів туризму, в тому числі сільського).

14. Недостатня державна підтримка розвитку туризму в регіонах в тому числі фінансова.

15. Недосконалість законодавчої та нормативно-правової бази в галузі туризму, неналежний стан туристичних маршрутів (брак обладнаних місць для перепочинку, гірських 


\section{ВИКОРИСТАННЯ МАРКЕТИНГОВИХ ІНСТРУМЕНТІВ В УМОВАХ ТРАНСФОРМАЦЇ̈ РЕГІОНАЛЬНОГО РИНКУ ТУРИЗМУ}

притулків, відсутність єдиної системи маркування), недостатній розвиток інфраструктури розваг для різних вікових i соціальних груп населення, недосконалість бази даних туристично-рекреаційних об'єктів.

16. Відсутність чіткої розробленої концепції та стратегії формування та розвитку туристичних дестинацій.

До можливостей варто віднести:

1. Формування туристичних дестинацій як умови ефективного використання туристичного потенціалу.

2. Формування організаційноінституціональних та економічних умов для розвитку туризму в найбільш привабливих територіях.

3. Активне використання ОТГ як базових територій для формування туристичних дестинацій.

4. Стратегічний розвиток туристичних комплексів та формування дестинацій в областях на основі створення туристичних кластерів.

5. Створення туристичних дестинацій на засадах регіональної співпраці в рамках єврорегіонів «Буг», «Карпатський», «Верхній Прут».

6. Просування туристичних продуктів областей на національному та міжнародному туристичних ринках.

7. Розвиток гірськолижного та інших видів зимового туризму.

8. Розвиток екстремального, спортивного, мисливського, рибальського туризму.

9. Розвиток сільського, зеленого, екологічного туризму.

10. Організація етнічних турів 3 прикордонних регіонів сусідніх країн та для діаспори.

11. Розвиток паломницького релігійного туризму.

12. Використання

транспортних можливостей областей як транзитних територій.

13. Розвиток культурно-пізнавального туризму 3 акцентом на відвідування пам'яток, внесених до списку світової спадщини «Юнеско».

14. Розширення екскурсійної діяльності для студентської та шкільної молоді.

15. Проведення наукових конференцій, конгресів, симпозіумів.

16. Залучення інвестиційних ресурсів в туристичну інфраструктуру.

Основними загрозами для розвитку туризму можуть бути визнані:
1. Різке

уповільнення

зростання туристичного ринку у зв'язку з поширенням коронавірусу.

2. Конкуренція з боку сусідніх країн, які пропонують подібні і (або) кращі продукти.

3. Відсутність нормативно-правової бази щодо формування туристичних дестинацій.

4. Реклама та поширення на території прикордонних областей України туристичних послуг, що пропонуються для споживання на прикордонних територіях Польщі, Румунії, Словаччини, Угорщини.

5. Створення на територіях західноукраїнських прикордонних регіонів представництв та філій потужних іноземних та київських туристичних фірм.

6. Відсутність коштів на відновлення історико-архітектурних пам'яток.

7. Зниження рівня державного фінансування проектів та матеріально-технічної бази сфери туризму.

8. Незаконна вирубка лісів та ерозія грунтів на гірських схилах при проведенні лісозаготівельних робіт в лісах гірських територій областей.

9. Обміління Шацьких озер та інших водних об'єктів, їх забруднення та порушення режиму водоохоронних зон і прибережних смуг.

10. Виїзд на заробітки кваліфікованих працівників. Поширення непродуктивної самозайнятості та тіньового працевлаштування.

11. Деградація рекреаційних земель, розвиток зсувних процесів.

12. Порушення вимог природоохоронного законодавства в природно-рекреаційній сфері.

13. Відсутність належної уваги до проблем туристичної сфери 3 боку місцевих органів влади.

14. Ймовірні погані враження від відвідування областей у попередніх туристів.

Результатом аналізу зведеної матриці сильних та слабких сторін, можливостей та загроз за максимальними балами позицій і рангів $€$ відокремлення суттєвих та несуттєвих пунктів для визначення основних пріоритетних напрямків розвитку сфери туризму та формування туристичних дестинацій $\mathrm{y}$ західноукраїнських прикордонних регіонах. Відповідно, найсильнішими позиціями щодо регіонів-конкурентів в Україні $€$ наявність унікальних природно-рекреаційних (лікувальнооздоровчих) ресурсів, наявність культурноісторичних та архітектурних пам'яток світового рівня, історична спадщина міст і сіл, збереженість самобутньої культури та народних промислів, вдале географічне та геополітичне 
розташування,

національно-етнографічна особливість західноукраїнських областей, гостинне населення, вишукана різноманітна місцева кухня, Карпатські гори, функціонування єврорегіонів. Всі ці позиції оцінені у п’ять балів і $\epsilon$ найсильнішими серед сильних сторін західноукраїнських прикордонних областей.

Щодо вагомості чинників, які розширюють потенційні можливості західноукраїнських прикордонних областей, то найважливішими визначено такі: формування туристичних дестинацій як умови ефективного використання туристичного потенціалу, активне використання ОТГ як базових територій для формування туристичних дестинацій, стратегічний розвиток туристичних комплексів та формування дестинацій в областях на основі створення туристичних кластерів, просування туристичних продуктів областей на національному та міжнародному туристичних ринках, використання транспортних можливостей областей як транзитних територій, розвиток культурно-пізнавального туризму 3 акцентом на відвідування пам'яток, внесених до списку світової спадщини «ЮНЕСКО».

Одночасно, проведений аналіз засвідчує існування значної кількості загроз для успішного розвитку сфери туризму та формування туристичних дестинацій у західноукраїнських прикордонних регіонах. Це, зокрема, різке уповільнення зростання туристичного ринку у зв'язку з поширенням коронавірусу, конкуренція з боку сусідніх країн, які пропонують подібні або кращі продукти, відсутність нормативноправової бази щодо формування туристичних дестинацій, відсутність належної уваги до проблем туристичної сфери 3 боку місцевих органів влади та ін.

Висновки. Таким чином, в період пандемії відбувається активна трансформація регіонального ринку туризму, що спонукало до пошуку та використання сучасних маркетингових інструментів, серед яких окрім визначених вище, відмова від офлайну на користь онлайн-активності, зміна сенсу i формату повідомлень, які передаються аудиторії у зв'язку 3 тривожною ситуацією у світі, що спонукає вибудовувати нову контент-політику, підвищує значимість соціальних мереж та месенджерів, сучасних цифрових технологій. Проведення SWOT-аналізу сприяло розумінню того, що не всі сильні сторони та ресурси (можливості) використовуються повністю. Маючи конкурентні переваги у близькості до кордону, функціонуванні єврорегіонів «Буг», «Карпатський», «Верхній Прут» та встановлені транскордонні туристичні контакти, необхідно в найближчий час створити організаційно-правові умови для формування туристичних дестинацій різних за масштабами, цілями, видами, спеціалізацією та іншими критеріями класифікації.

\section{Список літератури}

1. Жаліло, Я. А., Ковалівська, С. В., Филипенко, А. О., Химинець, В. В. та Головка, А. А. Щодо розвитку туризму в Україні в умовах підвищених епідемічних ризиків: аналітична записка Національного інституту стратегічних досліджень, 2019. URL: https://niss.gov.ua/sites/default/files/2020-06/turyzm-v-ukraini.pdf [Дата звернення 22 березня 2021 p.].

2. Липчук В. В., Липчук Н. В. Тренди в туризмі: корекція пандемії. Науковий погляд: економіка та управління. 2020. №2 (68). С. 33-37.

3. Білецький М. І., Котик Л. І. Віртуальний туризм як можливість популяризації історикокультурних пам'яток Сколівського району Львівської області / Історико-культурні пам'ятки Прикарпаття та Карпат - важливі об'єкти в розвитку туризму : матер. наук.-практ. конф. Львів : ЛІЕТ, 2019. С. 187-194.

4. Білецький М. І., Котик Л. І. Туризм як інноваційний вектор розвитку господарства Львівської області / Сучасні проблеми розвитку туризму в Україні : зб. матер. міжнар. наук. практ. конф. (Львів, 16 травня 2019 р.). Львів : Галич-Прес, 2019. С. 77-87.

5. Які культурні події Львова доступні онлайн у вихідні 9-11 квітня. URL: https://zaxid.net/podiyi_lvova_onlayn_9_11_kvitnya_2021_afisha_u_vihidni_n1517013.

6. Page S. J. Connell J. Tourism: a Modern Synthesis. - London: Cenpage Learning, EMEA, 2009. 663 p. 


\section{References}

1. Zhalilo, Ya. A., Kovalivska, C. V., Filipenko, A. O., Khiminets, V. V. and Golovka, A. A. (2019). Regarding the development of tourism in Ukraine in conditions of increased epidemic risks: an analytical note of the National Institute for Strategic Studies. Available at: https://niss.gov.ua/sites/default/files/2020-06/turyzm-v-ukraini.pdf [Accessed March 22, 2021].

2. Lypchuk, V. V., Lypchuk, N. V. (2020). "Trends in tourism: correction of the pandemic". Naukovyy pohlyad: ekonomika ta upravlinnya. № 2 (68). Pp. 33-37.

3. Biletsky, M.I., Kotyk, L.I. (2019). "Virtual tourism as an opportunity to popularize historical and cultural monuments of Skoliv district of Lviv region". Istoryko-kul'turni pam"yatky Prykarpattya ta Karpat vazhlyvi ob"yekty v rozvytku turyzmu [Historical and cultural monuments of Prykarpattia and Carpathians important objects in the development of tourism]. Lviv: LIET. Pp. 187-194.

4. Biletsky, M.I., Kotyk, L.I. (2019). "Tourism as an innovative vector of economic development of Lviv region". Suchasni problemy rozvytku turyzmu v Ukrayini [Modern problems of tourism development in Ukraine]. Lviv: Halych-Press. Pp. 77-87.

5. Yaki kul'turni podiyi L'vova dostupni onlayn u vykhidni 9-11 kvitnya. Available at: https://zaxid.net/podiyi_lvova_onlayn_9_11_kvitnya_2021_afisha_u_vihidni_n1517013. [Accessed April 22, 2021].

6. Page S. J. Connell J. (2009). Tourism: a Modern Synthesis. Cenpage Learning, London, England.

\section{Аннотация}

Александр Кифяк

\section{ИСПОЛЬЗОВАНИЕ МАРКЕТИНГОВЫХ ИНСТРУМЕНТОВ В УСЛОВИЯХ ТРАНСФОРМАЦИИ РЕГИОНАЛЬНОГО РЫНКА ТУРИЗМА}

В статье определены основные маркетинговые инструменты, которые могут быть использованы в современных условиях трансформации регионального рынка туризма, в частности, диджитализация системы сбыта и продвижения туристического продукта, интенсификаџия рекламы, ориентация на маркетинговое ценообразование, использование системы связей с общественностью и активизация маркетинговых исследований. Особое внимание в статье сосредоточено на результатах SWOT-анализа туристического потенциала западноукраинских приграничных территорий.

Ключевые слова: маркетинговые инструменты, туризм, дестинации, диджитализация, SWOT-анализ.

\section{Summary \\ USE OF MARKETING TOOLS IN THE CONDITIONS OF THE REGIONAL TOURISM MARKET TRANSFORMATION}

The purpose of this publication is to find opportunities to use marketing tools in the transformation of the regional tourism market by studying the best practices of foreign and Ukrainian experience, marketing research and analysis of the potential of the western Ukrainian border regions.

The article identifies the main marketing tools that can be used in the current transformation of the regional tourism market, including digitalization of sales and promotion of tourism products, intensification of advertising, focus on marketing pricing, use of public relations and intensification of marketing research. For this purpose, the results of the author's marketing research, analysis of professional literature, surveys of heads of local travel companies were used in the work. Particular attention in the article is focused on the results of the SWOT-analysis of the tourist potential of the western Ukrainian border areas. The main advantages and disadvantages inherent in border regions are identified, as well as the existing opportunities and threats that hinder the effective development of tourism. On the basis of the received results it is offered to create organizational and legal conditions for formation of various on scales, the purposes, kinds, specialization of tourist destinations.

Key words: marketing tools, tourism, destination, digitalization, SWOT-analysis. 